\title{
miR-1290 and its potential targets are associated with characteristics of estrogen receptor $\alpha$-positive breast cancer
}

\author{
Yumi Endo', Tatsuya Toyama', Satoru Takahashi ${ }^{2}$, Nobuyasu Yoshimoto', Mai Iwasa', \\ Tomoko Asano', Yoshitaka Fujii' and Hiroko Yamashita'
}

Departments of ${ }^{1}$ Oncology, Immunology and Surgery ${ }^{2}$ Experimental Pathology and Tumor Biology, Nagoya City University Graduate School of Medical Sciences, 1 Kawasumi, Mizuho-cho, Mizuho-ku, Nagoya 467-8601, Japan

H Yamashita is now at Breast and Endocrine Surgery, Hokkaido University Hospital, Kita 14, Nishi 5, Sapporo 060-8648, Japan
Correspondence should be addressed to $\mathrm{H}$ Yamashita Email

hirokoy@huhp.hokudai.ac.jp

\begin{abstract}
Recent analyses have identified heterogeneity in estrogen receptor $\alpha(E R \alpha)$-positive breast cancer. Subtypes called luminal A and luminal B have been identified, and the tumor characteristics, such as response to endocrine therapy and prognosis, are different in these subtypes. However, little is known about how the biological characteristics of ER-positive breast cancer are determined. In this study, expression profiles of microRNAs (miRNAs) and mRNAs in ER-positive breast cancer tissue were compared between $\mathrm{ER}^{\text {high }} \mathrm{Ki}^{\mathrm{low}}{ }^{\text {low }}$ tums and $\mathrm{ER}^{\text {low }} \mathrm{Ki}^{\mathrm{h}} 7^{\text {high }}$ tumors by miRNA and mRNA microarrays. Unsupervised hierarchical clustering analyses revealed distinct expression patterns of miRNAs and mRNAs in these groups. We identified a downregulation of miR-1290 in ER ${ }^{\text {high }} \mathrm{Ki} 7^{\text {low }}$ tumors. Among 11 miRNAs that were upregulated in $\mathrm{ER}^{\text {high }} \mathrm{Ki}^{\mathrm{low}} 7^{\text {low }}$ tumors, quantitative RT-PCR detection analysis using 64 samples of frozen breast cancer tissue identified six miRNAs (let-7a, miR-15a, miR-26a, miR-34a, miR-193b, and miR-342-3p). We picked up 11 genes that were potential target genes of the selected miRNAs and that were differentially expressed in ER ${ }^{\text {high }} \mathrm{Ki}^{\mathrm{low}}{ }^{\text {low }}$ tumors and $\mathrm{ER}^{\text {low }} \mathrm{Ki} 67^{\text {high }}$ tumors. Protein expression patterns of the selected target genes were analyzed in 256 ER-positive breast cancer samples by immunohistochemistry: miR-1290 and its putative targets, BCL2, FOXA1, MAPT, and NAT1, were identified. Transfection experiments revealed that introduction of miR-1290 into ER-positive breast cancer cells decreased expression of NAT1 and FOXA1. Our results suggest that miR-1290 and its potential targets might be associated with characteristics of ER-positive breast cancer.
\end{abstract}
Key Words
- breast cancer
- microRNA
- estrogen receptor
- miR-1290

Endocrine-Related Cancer (2013) 20, 91-102

\section{Introduction}

There are large-scale molecular differences between estrogen receptor $\alpha(E R \alpha)$-positive and ER-negative breast cancers (Sorlie et al. 2003). ER is essential for estrogendependent growth, and its level of expression is a crucial determinant of response to endocrine therapy and prognosis in ER-positive breast cancer (Harvey et al. 1999, Yamashita et al. 2006, Dowsett et al. 2008). Recent analyses have identified heterogeneity in ER-positive http://erc.endocrinology-journals.org DOI: 10.1530/ERC-12-0207
(C) 2013 Society for Endocrinology Printed in Great Britain 
breast cancer. Subtypes, named luminal A and luminal B, have been defined according to expression levels of Ki67, and the characteristics of these two subtypes are different (Goldhirsch et al. 2011). There is no doubt that higher concentrations of ER in the tumor cells are associated with a greater likelihood of a favorable response to endocrine therapy. However, little is known about how the expression of ER in breast cancer cells is regulated and how the biological characteristics of ER-positive breast cancer are determined. We recently analyzed expressions of microRNAs (miRNAs) that directly target ER in breast cancer. We found that miR-206 and miR-18a were downregulated in ER-positive breast cancer compared with ER-negative tumors and that low miR-18b expression was significantly associated with improved survival in HER2-negative breast cancer, although miR-18b expression was not correlated with ER protein expression (Kondo et al. 2008, Yoshimoto et al. 2011).

miRNAs are small ( $\sim 21$ nucleotides) noncoding RNAs that negatively regulate target genes by predominantly binding to the $3^{\prime}$-untranslated region (3'-UTR) of target mRNA, resulting in either mRNA degradation or translational repression (Krol et al. 2010). Recent studies have shown that miRNA mutations or dysregulated expression were associated with various human cancers and indicated that miRNAs can function as tumor suppressor genes and oncogenes (Esquela-Kerscher \& Slack 2006). Expression profiling also revealed that miRNAs are differently expressed among molecular subtypes of breast cancer (Iorio et al. 2005). Significant associations were found between miRNA expression profiles and clinicopathological factors such as ER status and tumor grade (Blenkiron et al. 2007). Furthermore, recent studies have demonstrated that loss- or gain-of-function of specific miRNAs contributes to breast epithelial cellular transformation, tumorigenesis, and epithelial-mesenchymal transition and metastasis (Zhang \& Ma 2012).

In this study, expression profiles of miRNAs and mRNAs in ER-positive breast cancer tissue were compared between $\mathrm{ER}^{\text {high }} \mathrm{Ki} 67^{\text {low }}$ tumors and $\mathrm{ER}^{\text {low }} \mathrm{Ki} 67^{\text {high }}$ tumors by miRNA and mRNA microarrays. Unsupervised hierarchical clustering analyses revealed distinct expression patterns of miRNAs and mRNAs in these two groups. We demonstrated that miR-1290 was downregulated and that six miRNAs were upregulated in $\mathrm{ER}^{\text {high }} \mathrm{Ki} 67^{\text {low }}$ tumors. Protein expression patterns of the predicted target genes and the genes that were identified by mRNA expression profiling were analyzed in ER-positive breast cancer samples by immunohistochemistry (IHC). We identified miR-1290 and its potential target genes, forkhead box A1 (FOXA1) and $N$-acetyltransferase-1 (NAT1), being associated with characteristics of ER-positive breast cancer.

\section{Materials and methods}

\section{Patients and breast cancer tissue}

Breast tumor specimens from female patients with invasive breast carcinoma who were treated at Nagoya City University Hospital between 1995 and 2010 were included in the study (Table 1). The study protocol was approved by the institutional review board and conformed to the guidelines of the 1996 Declaration of Helsinki. Written informed consent for the use of surgically resected tumor tissues was provided by all patients before treatments. The samples were chosen from a continuous series of invasive carcinoma. All patients except those with stage IV disease underwent surgical treatment (mastectomy or lumpectomy). Tumor samples of patients with stage IV disease were taken by core needle biopsy. Patients received adequate endocrine or chemotherapy for adjuvant or metastatic diseases.

\section{Microarray profiling of miRNA and mRNA expression}

Total RNA was extracted from eight frozen samples of breast cancer tissue (Table 1). Extracted total RNA was labeled with Hy5 using the miRCURY LNA Array miR labeling kit (Exiqon, Vedbaek, Denmark). Labeled RNAs were hybridized onto 3D-Gene Human miRNA Oligo chips containing 1011 antisense probes printed in duplicate spots (Toray, Kamakura, Japan). The annotation and oligonucleotide sequences of the probes were conformed to the miRBase miRNA data base (http://microrna.sanger. ac.uk/sequences/). After stringent washes, fluorescent signals were scanned with the ScanArray Express Scanner (PerkinElmer, Waltham, MA, USA) and analyzed using GenePix Pro version 5.0 (Molecular Devices, Sunnyvale, CA, USA). These raw data of each spot were normalized by substitution with the mean intensity of the background signal determined by all blank spots' signal intensities at 95\% confidence intervals. Measurements of both duplicate spots with signal intensities $>2$ s.D. of the background signal intensity were considered to be valid. A relative expression level of a given miRNA was calculated by comparing the signal intensities of the averaged valid spots with their mean value throughout the microarray experiments after normalization by their median values adjusted equivalently. miRNAs differentially expressed

Published by Bioscientifica Ltd. 
among the $\mathrm{ER}^{\text {high }} \mathrm{Ki} 67^{\text {low }}$ tumors and $\mathrm{ER}^{\text {low }} \mathrm{Ki} 67^{\text {high }}$ tumors were statistically identified using the Student's $t$-test and unsupervised hierarchical clustering analyses. Hierarchical clustering was performed with average linkage and Pearson's correlation. Differential expression was assessed by a nonparametric Wilcoxon's rank sum test for comparison between two groups. A heat-map was constructed by hierarchical clustering analysis using Cluster 2.0 Software (Tokyo, Japan) and the results were displayed with the TreeView program (http://rana.lbl.gov/ eisen/). miRNA expression data are available from the National Center for Biotechnology Gene Expression Omnibus (GEO) at accession number (GEO:GSE38280).

mRNA expression profiles were examined using the same frozen breast cancer tissue samples as those used in miRNA analyses. Extracted total RNA was labeled with Cy5 using the Amino Allyl MessageAMP II aRNA Amplification kit (Applied Biosystems). Labeled RNAs were hybridized onto 3D-Gene Human mRNA Oligo chips 25k (Toray) was used (25 370 distinct genes). Hybridization signals were scanned and detected by the same method as that used in miRNA analyses. The gene expression data are available from GEO at accession number (GEO:GSE38280).

\section{Quantitative RT-PCR detection of miRNAs}

Total RNA was extracted from $\sim 500 \mathrm{mg}$ frozen breast cancer tissue using TRIzol reagent (Life Technologies, Inc.) as described previously (Kondo et al. 2008). cDNA was reverse transcribed from total RNA samples using specific miRNA primers from the TaqMan MicroRNA Assays and reagents from the TaqMan MicroRNA RT Kit (Applied Biosystems). The resulting cDNA was amplified by PCR using TaqMan MicroRNA Assay primers with the TaqMan Universal PCR Master Mix and analyzed with a 7300 ABI PRISM Sequence Detector System according to the manufacturer's instructions (Applied Biosystems). The relative levels of miRNA expression were calculated from the relevant signals by normalization with the signal for $U 6 B$ miRNA expression. The assay names for each miRNA were as follows: hsa-let-7a for let-7a, hsa-miR-10a for miR-10a, hsa-miR-10b for miR-10b, hsa-miR-15a for 15a, hsa-miR-18a for miR-18a, hsa-miR-26a for miR-26a, hsa-miR-29c for miR-29c, hsa-miR-34a for miR-34a, hsa-miR-129 for miR-129, hsa-miR-146a for miR-146a, hsa-miR-193b for miR-193b, hsa-miR-342-3p for miR-342-3p, hsa-miR-1290 for miR-1290, and RNU6B for U6B miRNA (Applied Biosystems).

\section{Immunohistochemistry}

Tissue microarrays were constructed using paraffinembedded, formalin-fixed tissue from 256 ER-positive breast cancer samples, including 64 samples from patients whose frozen samples were used in miRNA expression analysis. Tissue array sections were immunostained with 15 commercially available antibodies using the Bond-Max Autostainer (Leica Microsystems, Newcastle, UK) and the associated Bond Refine Polymer Detection Kit (Yamashita et al. 2006). Details of primary antibodies and scoring manners are described in Supplementary Table 1, see section on supplementary data given at the end of this article. HER2-positive tumors were excluded from this study.

\section{Cell culture and transfections}

MCF-7 cells (American Type Culture Collection (ATCC), Manassas, VA, USA) were grown in RPMI 1640 medium containing $10 \%$ fetal bovine serum (FBS), $2 \mathrm{mmol} / \mathrm{l}$ L-glutamine and penicillin-streptomycin $(50 \mathrm{IU} / \mathrm{ml}$ and $50 \mathrm{mg} / \mathrm{ml}$ respectively), and $0.1 \%$ human insulin at $37^{\circ} \mathrm{C}$ with 5\% $\mathrm{CO}_{2}$. T47D cells (ATCC) were grown in RPMI 1640 medium containing 10\% FBS and $2 \mathrm{mmol} / \mathrm{l} \mathrm{L}$-glutamine and penicillin-streptomycin $(50 \mathrm{IU} / \mathrm{ml}$ and $50 \mathrm{mg} / \mathrm{ml}$ respectively) at $37^{\circ} \mathrm{C}$ with $5 \% \mathrm{CO}_{2}$. Transfections of premiR-1290 precursor (hsa-miR-1290; Ambion, Inc., Austin, TX, USA) were performed with Cell Line Nucleofector kits (Amaxa Biosystems, Cologne, Germany) using a Nucleofector device (Amaxa Biosystems) according to the manufacturer's instructions (Kondo et al. 2008). A nonspecific control miRNA (Pre-miR miRNA Inhibitors-Negative Control \#1; Ambion, Inc.) was used as a negative control.

\section{Quantitative RT-PCR detection of miR-1290 and mRNAs}

Total RNA was extracted from $2 \times 10^{6}$ cells with miRNeasy Mini Kit (Qiagen) using a QIAcube (Qiagen) according to the manufacturer's instructions. cDNA was reverse transcribed using specific miRNA primers and the relative levels of miR-1290 expression were measured as described earlier. Total RNA ( $1 \mu \mathrm{g})$ was also subjected to RT with random primers in a $20 \mu \mathrm{l}$ reaction volume using High-Capacity cDNA RT Kit (Applied Biosystems). mRNA expression was measured by quantitative RT-PCR with the TaqMan Universal PCR Master Mix using a 7500 ABI PRISM Sequence Detector System according to the manufacturer's instructions (Applied Biosystems; Kondo et al. 2008). The relative levels of mRNA expression were

Published by Bioscientifica Ltd 
Table 1 Clinicopathological characteristics of patients and breast tumors with ER-positive, HER2-negative breast cancer.

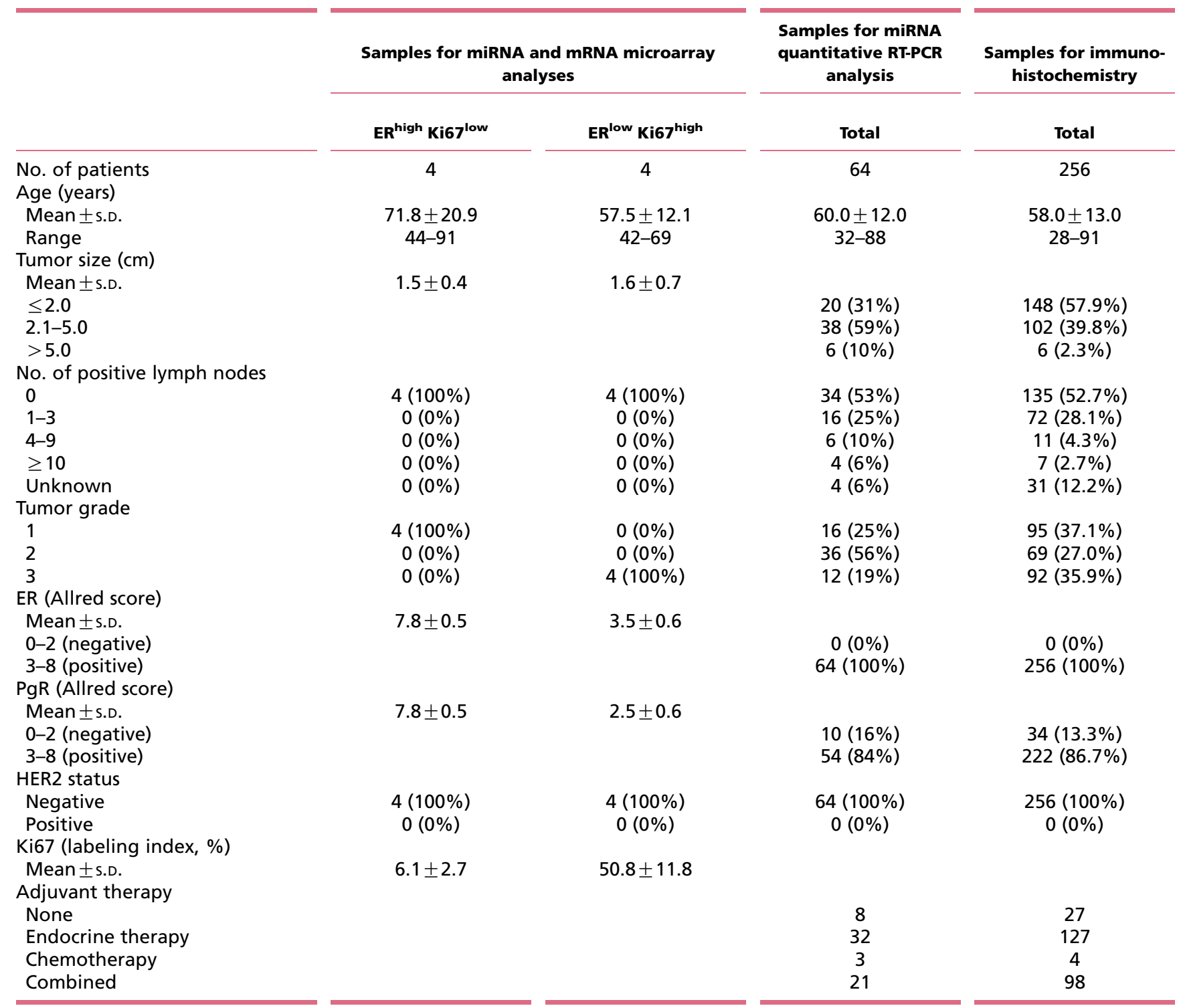

calculated from the relevant signals by normalization with the signal for $\beta$-actin mRNA expression. The assay numbers for BCL2, FOXA1, microtubule-associated protein tau (MAPT), NAT1, and $\beta$-actin were as follows: Hs00608023_m1 for BCL2, Hs00270129_m1 for FOXA1, Hs00902314_m1 for MAPT, Hs00265080_m1 for NAT1, and $4333762 \mathrm{~T}$ for $\beta$-actin (Applied Biosystems).

\section{Western blotting}

Cells were pelleted by centrifugation and solubilized in lysis buffer containing protease inhibitor and phosphatase inhibitor cocktails (Thermo Scientific, Yokohama, Japan). Equal amounts of total protein $(30 \mu \mathrm{g})$ from whole cell lysates were prepared and electrophoresed on $12 \%(\mathrm{w} / \mathrm{v})$ SDS-polyacrylamide gels (NuPAGE Bis-Tris Gel, Invitrogen) transferred to polyvinylidene difluoride membranes (Invitrogen) and immunoblotted using specific antibodies (Supplementary Table 1; Yamashita et al. 2003). Antimouse or anti-rabbit IgG, HRP-linked Whole Antibodies (GE Healthcare Japan, Tokyo, Japan) were used as secondary antibodies at 1:10 000 dilution. Antibody binding was visualized with ECL Western Blotting Detection System (GE Healthcare Japan) using LightCapture AE-6981 (ATTO, Tokyo, Japan) according to the manufacturer's instructions. Image J Software from the National Institutes of Health (Bethesda, MD, USA) was used to quantify band intensities. 


\section{Statistical analysis}

Spearman's rank correlation test was used to study relationships between expression levels of miRNAs and clinicopathological factors, expression levels of proteins and clinicopathological factors, expression levels of miRNAs and proteins, and expression levels of miRNAs and mRNAs. $P<0.05$ is considered significant in Spearman's rank correlation test.

\section{Results}

\section{Differentially expressed miRNAs in ER ${ }^{\text {high }} \mathrm{Ki} 67^{\text {low }}$ tumors and $E R^{\text {low }} \mathrm{Ki}^{\mathrm{high}}$ tumors in breast cancer tissue}

Expression profiles of miRNAs and mRNAs in ER-positive breast cancer tissue were compared between $\mathrm{ER}^{\text {high }} \mathrm{Ki} 67^{\text {low }}$ tumors and $\mathrm{ER}^{\text {low }} \mathrm{Ki} 67^{\text {high }}$ tumors by miRNA and mRNA microarrays using eight frozen samples of breast cancer tissue (four tumors in each group; Table 1). Unsupervised hierarchical clustering analyses revealed 67 miRNAs in 1011 miRNAs and 657 mRNAs in 25370 mRNAs that were differentially expressed in $\mathrm{ER}^{\text {high }} \mathrm{Ki} 67^{\text {low }}$ tumors and $\mathrm{ER}^{\text {low }}$ Ki67 $7^{\text {high }}$ tumors $(P<0.01$; Supplementary Figure 1 , see section on supplementary data given at the end of this article and Supplementary Table 2, see section on supplementary data given at the end of this article, and $P<0.01$; Supplementary Figure 2, see section on supplementary data given at the end of this article and Supplementary Tables 3 and 4, see section on supplementary data given at the end of this article respectively). We selected 12 miRNAs (let-7a, miR-10a, miR-10b, miR15a, miR-26a, miR-29c, miR-34a, miR-129, miR-146a, miR193b, miR-342-3p, and miR-1290) that were differentially expressed in these two groups. Among differentially expressed 67 miRNAs, the above 12 miRNAs, especially let-7a, miR-10a, miR-10b, miR-15a, miR-26a, miR-29c, miR-34a, miR-146a, and miR-342-3p, have been reported to be related to breast cancer development and carcinogenesis (Mattie et al. 2006, Blenkiron et al. 2007, O'Day \& Lal 2010). miR-193b has been reported to be related to ER $\alpha$ (Yoshimoto et al. 2011). Moreover, we referred to the reported mRNA microarray analyses to classify luminal A and luminal B subtypes in order to select key genes (Sorlie et al. 2003, Parker et al. 2009), including FOXA1, NAT1, $M A P T, X B P 1$, and $B C L 2$, which have target sequences in the $3^{\prime}$-UTR regions of 67 differentially expressed miRNAs according to in silico analysis using TargetScan, PicTar, and MiRanda, and selected miR-146a and miR-1290, which were downregulated in $\mathrm{ER}^{\text {high }} \mathrm{Ki} 67^{\text {low }}$
Table 2 Expression levels of 12 selected miRNAs and the control miRNA (U6B) in 64 ER-positive breast cancer tissues by quantitative RT-PCR analysis.

\begin{tabular}{|c|c|}
\hline & Mean \pm s.E.M. \\
\hline let-7a & $22.079 \pm 0.173$ \\
\hline miR-10a & $26.585 \pm 0.278$ \\
\hline miR-10b & $27.636 \pm 0.247$ \\
\hline miR-15a & $27.100 \pm 0.285$ \\
\hline miR-26a & $22.711 \pm 0.201$ \\
\hline miR-29c & $24.295 \pm 0.390$ \\
\hline miR-34a & $26.339 \pm 0.240$ \\
\hline mR-129 & $34.759 \pm 0.185$ \\
\hline miR-146a & $26.160 \pm 0.221$ \\
\hline miR-193b & $21.112 \pm 0.219$ \\
\hline miR-342-3p & $24.456 \pm 0.322$ \\
\hline miR-1290 & $27.612 \pm 0.445$ \\
\hline U6B & $27.091 \pm 0.154$ \\
\hline
\end{tabular}

tumors. Quantitative RT-PCR detection analysis using 64 frozen breast cancer tissue samples (Table 2 and Supplementary Table 5, see section on supplementary data given at the end of this article) identified six miRNAs (let-7a, miR-15a, miR-26a, miR-34a, miR-193b, and miR-342-3p) that were upregulated in $\mathrm{ER}^{\text {high }}$ tumors $(P=0.0002, P=0.0006, P=0.0082, P<0.0001, P=0.0142$, and $P=0.0002$ respectively; Table 3 ). miR-1290 was also included in further analyses because it was the only miRNA among the selected miRNAs that was downregulated in $\mathrm{ER}^{\text {high }} \mathrm{Ki} 67^{\text {low }}$ tumors and its expression levels were strongly correlated with tumor grade $(P<0.0001$; Table 3).

The potential target genes for seven selected miRNAs (let-7a, miR-15a, miR-26a, miR-34a, miR-193b, miR-342$3 \mathrm{p}$, and miR-1290) were predicted according to in silico analysis using TargetScan, PicTar, and MiRanda. In addition, 657 mRNAs that were differentially expressed in $\mathrm{ER}^{\text {high }} \mathrm{Ki} 67^{\text {low }}$ tumors and $\mathrm{ER}^{\text {low }} \mathrm{Ki} 67^{\text {high }}$ tumors in microarray analysis were considered to select putative target genes. Finally, we picked up 11 proteins (ANKRD30, BCL2, cyclin D1, FOXA1, GATA3, LIN28, MAPT, NAT1, RB1, P53 (TP53), and XBP1) that were products of potential target genes for seven selected miRNAs and that were considered to be differentially expressed in $\mathrm{ER}^{\text {high }} \mathrm{Ki} 67^{\text {low }}$ tumors and $\mathrm{ER}^{\text {low }} \mathrm{Ki} 67^{\text {high }}$ tumors (Table 4 ). $A N K R D 30$ was the most differentially expressed gene between $\mathrm{ER}^{\text {high }} \mathrm{Ki} 67^{\text {low }}$ tumors and $\mathrm{ER}^{\text {low }} \mathrm{Ki} 67^{\text {high }}$ tumors. BCL2, cyclin D1, LIN28, and RB1 are potential targets of the selected miRNAs as shown in Table 4. FOXA1, GATA3, NAT1, and XBP1 were strongly downregulated in $\mathrm{ER}^{\text {low }}$ Ki $67^{\text {high }}$ tumors, putative targets of the selected miRNAs, and reported as to be related with ER-positive breast

Published by Bioscientifica Ltd 
Table 3 Correlation between expression levels of miRNAs and clinicopathological factors $(n=64)$.

\begin{tabular}{|c|c|c|c|c|c|}
\hline & ER & PgR & Tumor grade & Ki67 & Tumor size \\
\hline let-7a & $\begin{array}{l}+0.533^{\mathrm{a}} \\
0.0002^{*, \mathrm{~b}}\end{array}$ & $\begin{array}{l}+0.349 \\
0.0087 *\end{array}$ & $\begin{array}{r}-0.033 \\
0.2536\end{array}$ & $\begin{array}{r}-0.115 \\
0.3717\end{array}$ & $\begin{array}{r}-0.068 \\
0.5854\end{array}$ \\
\hline miR-10a & $\begin{array}{c}+0.286 \\
0.1114\end{array}$ & $\begin{array}{c}+0.219 \\
0.1113\end{array}$ & $\begin{array}{r}+0.005 \\
0.4012\end{array}$ & $\begin{array}{r}-0.113 \\
0.3757\end{array}$ & $\begin{array}{l}-0.326 \\
0.0098 *\end{array}$ \\
\hline miR-10b & $\begin{array}{c}+0.268 \\
0.1646\end{array}$ & $\begin{array}{c}+0.130 \\
0.3894\end{array}$ & $\begin{array}{c}+0.074 \\
0.8411\end{array}$ & $\begin{array}{r}-0.114 \\
0.375\end{array}$ & $\begin{array}{r}-0.185 \\
0.1439\end{array}$ \\
\hline miR-15a & $\begin{array}{l}+0.499 \\
0.0006^{*}\end{array}$ & $\begin{array}{r}+0.081 \\
0.6396\end{array}$ & $\begin{array}{c}+0.215 \\
0.3036\end{array}$ & $\begin{array}{r}+0.055 \\
0.6729\end{array}$ & $\begin{array}{c}-0.129 \\
0.3084\end{array}$ \\
\hline miR-26a & $\begin{array}{l}+0.414 \\
0.0082 *\end{array}$ & $\begin{array}{r}+0.165 \\
0.2585\end{array}$ & $\begin{array}{r}+0.065 \\
0.7953\end{array}$ & $\begin{array}{r}-0.056 \\
0.6674\end{array}$ & $\begin{array}{c}-0.003 \\
0.9712\end{array}$ \\
\hline miR-29c & $\begin{array}{c}+0.206 \\
0.3839\end{array}$ & $\begin{array}{r}-0.030 \\
0.6671\end{array}$ & $\begin{array}{r}+0.115 \\
0.8782\end{array}$ & $\begin{array}{r}+0.018 \\
0.8917\end{array}$ & $\begin{array}{r}-0.084 \\
0.5117\end{array}$ \\
\hline miR-34a & $\begin{array}{l}+0.785 \\
<0.0001 *\end{array}$ & $\begin{array}{r}+0.164 \\
0.2558\end{array}$ & $\begin{array}{r}+0.061 \\
0.7535\end{array}$ & $\begin{array}{r}+0.034 \\
0.7941\end{array}$ & $\begin{array}{r}-0.168 \\
0.1851\end{array}$ \\
\hline mR-129 & $\begin{array}{c}+0.334 \\
0.0528\end{array}$ & $\begin{array}{r}+0.043 \\
0.8722\end{array}$ & $\begin{array}{c}+0.334 \\
0.0384 *\end{array}$ & $\begin{array}{r}-0.056 \\
0.6711\end{array}$ & $\begin{array}{r}-0.006 \\
0.9746\end{array}$ \\
\hline miR-146a & $\begin{array}{c}+0.101 \\
0.9032\end{array}$ & $\begin{array}{r}-0.149 \\
0.1819\end{array}$ & $\begin{array}{l}+0.425 \\
0.0073^{*}\end{array}$ & $\begin{array}{r}+0.007 \\
0.9586\end{array}$ & $\begin{array}{r}-0.052 \\
0.6966\end{array}$ \\
\hline miR-193b & $\begin{array}{l}+0.387 \\
0.0142 *\end{array}$ & $\begin{array}{r}+0.203 \\
0.1483\end{array}$ & $\begin{array}{c}+0.223 \\
0.2666\end{array}$ & $\begin{array}{r}+0.078 \\
0.5493\end{array}$ & $\begin{array}{r}+0.046 \\
0.7298\end{array}$ \\
\hline miR-342-3p & $\begin{array}{l}+0.539 \\
0.0002 *\end{array}$ & $\begin{array}{r}+0.131 \\
0.3975\end{array}$ & $\begin{array}{l}+0.131 \\
0.8024\end{array}$ & $\begin{array}{r}-0.039 \\
0.7657\end{array}$ & $\begin{array}{r}-0.016 \\
0.8932\end{array}$ \\
\hline miR-1290 & $\begin{array}{c}+0.014 \\
0.3987\end{array}$ & $\begin{array}{c}-0.211 \\
0.0581\end{array}$ & $\begin{array}{l}+0.585 \\
<0.0001 *\end{array}$ & $\begin{array}{r}+0.228 \\
0.0748\end{array}$ & $\begin{array}{r}+0.029 \\
0.8267\end{array}$ \\
\hline
\end{tabular}

\begin{tabular}{l}
$\begin{array}{l}\text { No. of positive } \\
\text { lymph nodes }\end{array}$ \\
\hline+0.123 \\
0.7959 \\
+0.132 \\
0.7399 \\
+0.171 \\
0.5025 \\
+0.062 \\
0.7917 \\
+0.060 \\
0.8038 \\
+0.121 \\
0.7546 \\
+0.039 \\
0.6458 \\
+0.049 \\
0.677 \\
-0.009 \\
0.5031 \\
+0.214 \\
0.2889 \\
+0.107 \\
0.9081 \\
+0.280 \\
0.1109 \\
\hline
\end{tabular}

$* P<0.05$ is considered significant.

aspearman's correlation coefficient.

${ }^{\mathrm{b}} P$, Spearman's rank correlation test.

cancer. MAPT is also reported to be related with ER-positive breast cancer and a potential target of miR1290. P53 was selected as a target of let-7a.

\section{Expression of the potential target genes in ER-positive, HER2-negative breast cancer}

We examined protein expression of 11 selected target genes in ER-positive, HER2-negative breast cancer by IHC (Supplementary Table 6, see section on supplementary data given at the end of this article). Expression levels of BCL2, FOXA1, GATA3, LIN28, MAPT, and NAT1 were positively correlated with expression levels of ER $(P<0.0001, P<0.0001, P<0.0001, P=0.0008, P<0.0001$, and $P=0.0005$ respectively; Table 4$)$. Expression levels of ANKRD30, BCL2, FOXA1, GATA3, LIN28, MAPT, and NAT1 were positively correlated with expression levels of progesterone receptor (PgR; $P=0.0246, P=0.0059$, $P=0.0005, \quad P<0.0001, \quad P=0.017, \quad P<0.0001$, and $P<0.0001$ respectively). Expression levels of ANKRD30, BCL2, and TP53 were positively correlated with tumor grade $(P=0.0012, P=0.0109$, and $P=0.0108$ respectively), whereas expression levels of CCND1, FOXA1, GATA3,
LIN28, MAPT, NAT1, and XBP1 were negatively correlated with tumor grade $(P=0.0101, P<0.0001, P<0.0001$, $P=0.0099, P<0.0001, P<0.0001$, and $P=0.0018$ respectively). Expression levels of LIN28 and TP53 were positively correlated with expression levels of $\mathrm{Ki} 67$ ( $P=0.0446$ and $P=0.002$ respectively), while expression levels of MAPT and NAT1 were negatively correlated with expression levels of $\mathrm{Ki67}(P=0.0419$ and $P=0.0095$ respectively). Expression levels of ANKRD30, FOXA1, GATA3, LIN28, MAPT, NAT1, TP53, and XBP1 were negatively correlated with tumor size $(P<0.0001, P=0.0009, P=0.0001$, $P<0.0001, \quad P=0.0093, \quad P=0.0004, \quad P=0.0336$, and $P=0.0203$ respectively). There was no association between expression of 11 selected proteins and lymph node status (Table 4).

We then compared expression levels of seven selected miRNAs (let-7a, miR-15a, miR-26a, miR-34a, miR-193b, miR-342-3p, and miR-1290) and their potential target genes (ANKRD30, BCL2, cyclin D1, FOXA1, GATA3, LIN28, $M A P T, N A T 1, R B 1, P 53$, and XBP1) using 64 samples of breast cancer tissue, simultaneously analyzing miRNA expression by quantitative RT-PCR and protein expression by IHC. Interestingly, expression levels of miR-1290 were

Published by Bioscientifica Ltd. 
Table 4 Correlation between expression levels of potential target proteins and clinicopathological factors $(n=256)$.

\begin{tabular}{|c|c|c|c|c|c|c|c|}
\hline & ER & PgR & Tumor grade & Ki67 & Tumor size & $\begin{array}{l}\text { No. of positive } \\
\text { lymph nodes }\end{array}$ & miRNAs \\
\hline ANKRD30 & $\begin{array}{r}+0.260^{a} \\
0.2265^{b}\end{array}$ & $\begin{aligned} &+ 0.250 \\
& 0.0246 *\end{aligned}$ & $\begin{array}{r}+0.002 \\
0.0012 *\end{array}$ & $\begin{array}{r}+0.142 \\
0.5865\end{array}$ & $\begin{array}{l}-0.145 \\
<0.0001 *\end{array}$ & $\begin{array}{r}+0.176 \\
0.2769\end{array}$ & miR-193b \\
\hline BCL2 & $\begin{array}{l}+0.467 \\
<0.0001 *\end{array}$ & $\begin{aligned} &+ 0.320 \\
& 0.0059 *\end{aligned}$ & $\begin{array}{r}+0.102 \\
0.0109 *\end{array}$ & $\begin{array}{r}+0.132 \\
0.4585\end{array}$ & $\begin{array}{r}+0.078 \\
0.0968\end{array}$ & $\begin{array}{r}+0.278 \\
0.8608\end{array}$ & $\begin{array}{l}\text { let-7a, miR-10a, miR-15a, } \\
\text { miR-26a, miR-29c, } \\
\text { miR-34a, miR-1290 }\end{array}$ \\
\hline CCND1 & $\begin{array}{r}+0.177 \\
0.5364\end{array}$ & $\begin{array}{r}+0.083 \\
0.6216\end{array}$ & $\begin{array}{l}-0.190 \\
0.0101 *\end{array}$ & $\begin{array}{r}+0.078 \\
0.5415\end{array}$ & $\begin{aligned}-0.085 \\
0.4981\end{aligned}$ & $\begin{array}{r}+0.046 \\
0.6898\end{array}$ & $\begin{array}{l}\text { miR-15a, miR-34a, } \\
\text { miR-193b }\end{array}$ \\
\hline FOXA1 & $\begin{array}{l}+0.407 \\
<0.0001 *\end{array}$ & $\begin{array}{r}+0.234 \\
0.0005^{\star}\end{array}$ & $\begin{array}{l}-0.235 \\
<0.0001 *\end{array}$ & $\begin{array}{r}-0.082 \\
0.1939\end{array}$ & $\begin{array}{l}-0.210 \\
0.0009 *\end{array}$ & $\begin{array}{r}+0.009 \\
0.103\end{array}$ & miR-129, miR-1290 \\
\hline GATA3 & $\begin{array}{l}+0.448 \\
<0.0001 *\end{array}$ & $\begin{array}{l}+0.286 \\
<0.0001 *\end{array}$ & $\begin{array}{l}-0.224 \\
<0.0001 *\end{array}$ & $\begin{array}{c}-0.004 \\
0.9441\end{array}$ & $\begin{array}{l}-0.242 \\
0.0001 *\end{array}$ & $\begin{array}{r}-0.005 \\
0.0655\end{array}$ & miR-10a, miR-10b, miR-34a \\
\hline LIN28 & $\begin{array}{r}+0.289 \\
0.0008 *\end{array}$ & $\begin{array}{c}+0.173 \\
0.017 *\end{array}$ & $\begin{array}{l}-0.081 \\
0.0099 *\end{array}$ & $\begin{array}{r}+0.138 \\
0.0446 *\end{array}$ & $\begin{array}{l}-0.238 \\
<0.0001 *\end{array}$ & $\begin{array}{r}+0.068 \\
0.3681\end{array}$ & $\begin{array}{l}\text { let-7a, miR-26a, miR-34a, } \\
\text { miR-129, miR-342-3p }\end{array}$ \\
\hline MAPT & $\begin{array}{l}+0.356 \\
<0.0001 *\end{array}$ & $\begin{array}{l}0.494 \\
<0.0001 *\end{array}$ & $\begin{array}{l}-0.254 \\
<0.0001 *\end{array}$ & $\begin{array}{l}-0.144 \\
0.0419 *\end{array}$ & $\begin{array}{l}-0.149 \\
0.0093 *\end{array}$ & $\begin{array}{r}+0.030 \\
0.1314\end{array}$ & miR-34a, miR-1290 \\
\hline NAT1 & $\begin{array}{r}+0.316 \\
0.0005^{*}\end{array}$ & $\begin{array}{l}+0.394 \\
<0.0001 *\end{array}$ & $\begin{array}{l}-0.274 \\
<0.0001 *\end{array}$ & $\begin{array}{r}-0.122 \\
0.0095 *\end{array}$ & $\begin{array}{l}-0.180 \\
0.0004^{\star}\end{array}$ & $\begin{array}{r}+0.105 \\
0.4956\end{array}$ & miR-1290 \\
\hline RB1 & $\begin{array}{r}+0.248 \\
0.0751\end{array}$ & $\begin{array}{r}+0.261 \\
0.8369\end{array}$ & $\begin{array}{r}+0.327 \\
0.4651\end{array}$ & $\begin{array}{l}+0.290 \\
0.2424\end{array}$ & $\begin{array}{r}+0.263 \\
0.6956\end{array}$ & $\begin{array}{r}+0.374 \\
0.6748\end{array}$ & $\begin{array}{l}\text { let-7a, miR-26a, miR-34a, } \\
\text { miR-129, miR-1290 }\end{array}$ \\
\hline TP53 & $\begin{array}{r}-0.016 \\
0.0743\end{array}$ & $\begin{array}{r}-0.010 \\
0.6815\end{array}$ & $\begin{array}{r}+0.211 \\
0.0108 *\end{array}$ & $\begin{array}{r}+0.197 \\
0.002 *\end{array}$ & $\begin{array}{l}-0.133 \\
0.0336 *\end{array}$ & $\begin{array}{r}+0.074 \\
0.5783\end{array}$ & let-7a \\
\hline XBP1 & $\begin{array}{r}+0.183 \\
0.5653\end{array}$ & $\begin{array}{r}-0.042 \\
0.5318\end{array}$ & $\begin{array}{l}-0.236 \\
0.0018 *\end{array}$ & $\begin{array}{r}+0.079 \\
0.5906\end{array}$ & $\begin{array}{c}-0.278 \\
0.0203 *\end{array}$ & $\begin{array}{r}-0.040 \\
0.2069\end{array}$ & miR-34a \\
\hline
\end{tabular}

$\star P<0.05$ is considered significant.

aSpearman's correlation coefficient.

${ }^{\mathrm{b}} \mathrm{P}$, Spearman's rank correlation test.

inversely correlated with expression levels of $B C L 2$, FOXA1, MAPT, and NAT1, all of which are predictive targets of miR-1290 according to in silico analysis ( $P=0.020, P=0.044, P=0.040$, and $P=0.0098$ respectively; Fig. 1A, B, C and D), suggesting that miR-1290 might downregulate these four genes in ER-positive breast cancer. Moreover, let-7a expression was inversely correlated with P53 expression ( $P=0.038$; Fig. $1 \mathrm{E})$. No association was found between other miRNA expressions and their putative target gene expressions.

\section{miR-1290 downregulates FOXA1 and NAT1 in ER-positive breast cancer cells}

We extended our analysis to clarify whether miR-1290 downregulates BCL2, FOXA1, MAPT, and NAT1 in ER-positive breast cancer cells. Pre-miR-1290 precursor was introduced into T47D and MCF-7 cells. Cells were transfected with either control miRNA $(300 \mathrm{nmol} / \mathrm{l})$ or pre-miR-1290 precursor at various concentrations (10-300 nmol/l) and incubated for $24 \mathrm{~h}$ in T47D cells and for $36 \mathrm{~h}$ in MCF-7 cells. Expression levels of miR-1290 and mRNA expression levels of BCL2, FOXA1, MAPT, and NAT1 were quantitatively measured using parallel samples. Transfection with pre-miR-1290 produced a dose-dependent increase in miR-1290 expression levels (Fig. 2A, left), whereas expression levels of miR-1290 were inversely correlated with expression levels of FOXA1 $(P=0.0003$; Fig. 2A, top right $)$ and NAT1 $(P<0.0001$; Fig. 2A, bottom right) mRNAs, but not with $B C L 2$ or MAPT mRNA, in T47D cells (Fig. 2A). Moreover, expression levels of miR-1290 were inversely correlated with expression levels of NAT1 mRNA ( $P=0.037$; Fig. $2 \mathrm{~B}$, bottom right), but not with BCL2, FOXA1, or MAPT mRNA, in MCF-7 cells (Fig. 2B).

The effects of miR-1290 on protein expression of BCL2, FOXA1, MAPT, and NAT1 were examined in T47D and MCF-7 cells by western blot analysis. When T47D cells were transfected with either control miRNA (300 nmol/l) or pre-miR-1290 precursor at various concentrations (30-1000 nmol/l) and incubated for $48 \mathrm{~h}, \mathrm{miR}-1290$ induced a dose-dependent decrease in protein expression of NAT1, reducing it $\sim 60 \%$, but not BCL2, FOXA1, or MAPT (Fig. 2C). Effects of miR-1290 on protein expression of BCL2, FOXA1, MAPT, and NAT1 were not clear in MCF-7 cells (Fig. 2D). From these analyses, we conclude that miR-1290 might downregulate FOXA1 and NAT1 in ER-positive breast cancer cells. 

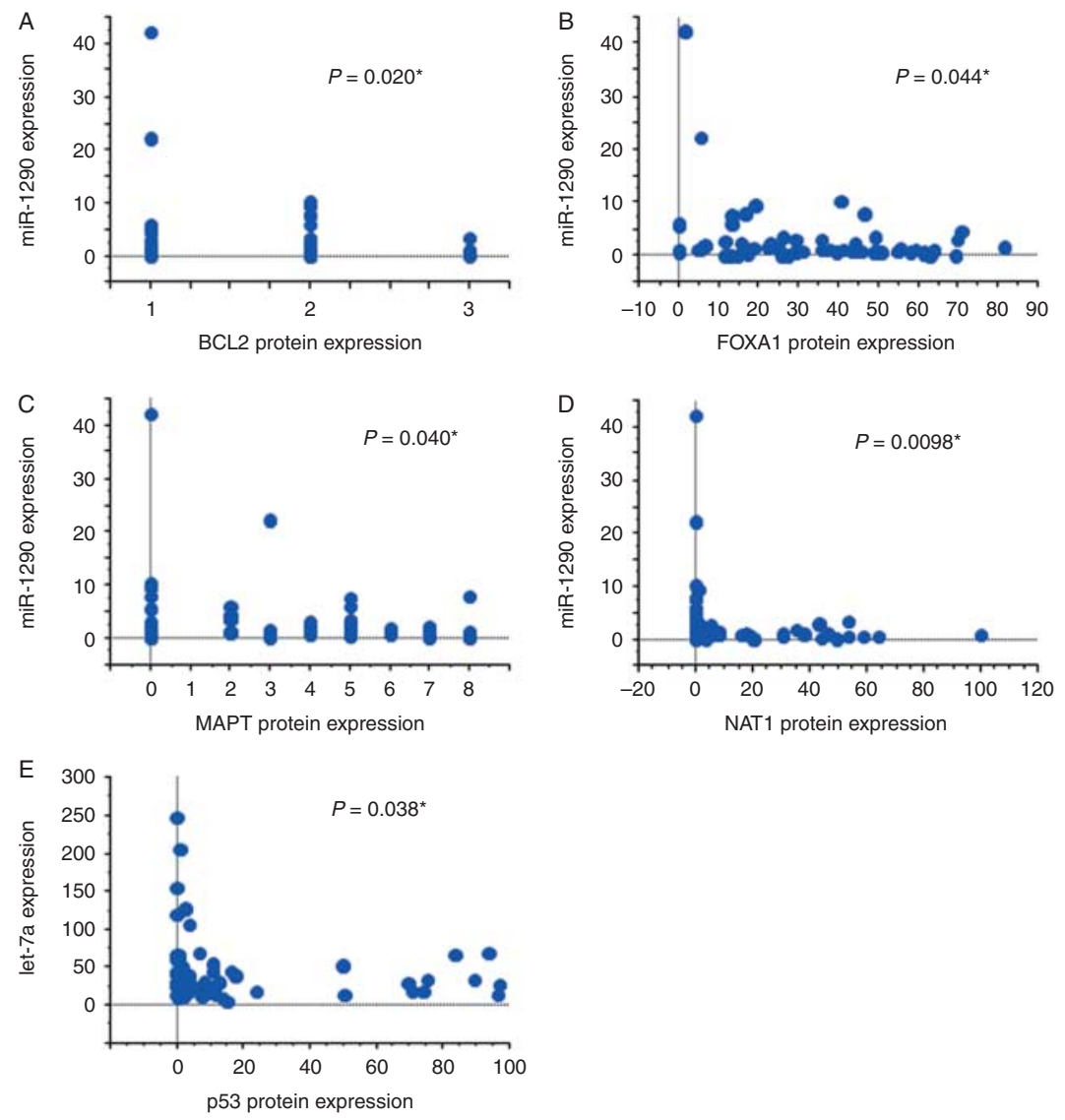

Figure 1

miR-1290 expression is inversely correlated with expressions of BCL2, FOXA1, MAPT, and NAT1. Scatter plots show inverse correlations between miR-1290 and BCL2 (A), FOXA1 (B), MAPT (C), and NAT1 (D) protein

\section{Discussion}

In this study, we have shown distinct expression patterns of miRNAs and mRNAs in luminal $A$ and luminal $B$ subtypes in ER-positive breast cancer. We demonstrated that miR-1290 and its potential target genes, FOXA1 and NAT1, might be associated with characteristics of ER-positive disease. miR-1290 expression was strongly downregulated in $\mathrm{ER}^{\text {high }} \mathrm{Ki} 67^{\text {low }}$ tumors and was positively correlated with tumor grade. Although the role of miR-1290 has not been analyzed as yet, it was reported that 36 miRNAs, including miR-1290, were circulating at increased levels in patients with renal cell carcinoma and were overexpressed in corresponding renal cell carcinoma tissue (Wulfken et al. 2011). It was also reported that six miRNAs, including miR-1290, were upregulated in drug-sensitive cells following Y-Box protein 1 inhibition, but no differences in miRNA

expression in breast cancer tissue $(P=0.020, P=0.044, P=0.040$, and $P=0.0098$ respectively). (E) let-7 expression is inversely correlated with P53 protein expression in breast cancer tissue $(P=0.038)$.

expression could be detected in multidrug-resistant gastric carcinoma cells (Belian et al. 2010).

FOXA1, a forkhead family transcription factor, has been reported to be expressed predominantly in luminal A breast cancer with favorable prognosis (Badve et al. 2007, Mehta et al. 2012). Hurtado et al. recently reported that FOXA1 creates an open conformation at ER-binding sites and that ER can bind and activate target gene expression in the presence of estrogen. Thus, FOXA1 is a key determinant of ER function and endocrine response in breast cancer (Hurtado et al. 2011). They also reported that the differential ER-binding program observed in tumors from patients with poor outcome is due to the FOXA1-mediated reprogramming of ER binding (Ross-Innes et al. 2012). We demonstrated that FOXA1 expression is much higher in $\mathrm{ER}^{\text {high }} \mathrm{Ki} 67^{\text {low }}$ tumors than in $\mathrm{ER}^{\text {low }} \mathrm{Ki} 67^{\text {high }}$ tumors and that expression levels of FOXA1 were strongly and positively correlated with expression levels of ER and

Published by Bioscientifica Ltd. 
A T47D
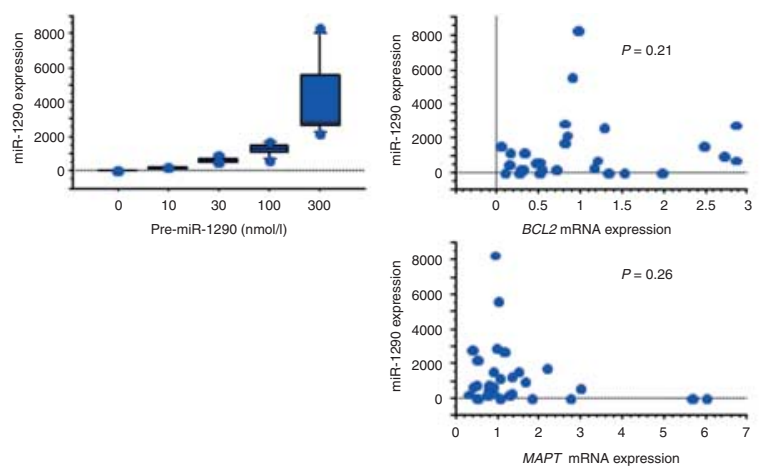

B $\quad$ MCF-7
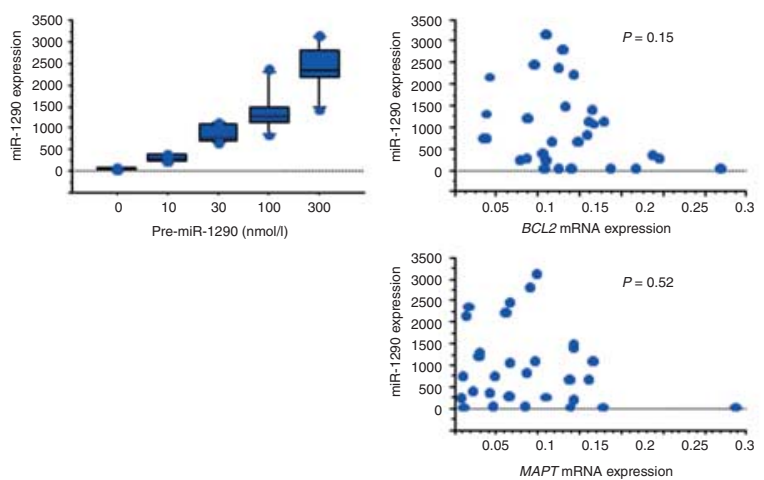

Figure 2

Gene expressions of miR-1290 putative targets in T47D and MCF-7 cells transfected with miR-1290. (A) T47D cells were transfected with either control miRNA ( $300 \mathrm{nmol} / \mathrm{l})$ or pre-miR-1290 precursor at $10-300 \mathrm{nmol} / \mathrm{l}$ and incubated for $24 \mathrm{~h}$. Expression levels of miR-1290 and mRNA levels of BCL2, FOXA1, MAPT, and NAT1 were measured by quantitative RT-PCR. Scatter plots show inverse correlation between miR-1290 expression and FOXA1 and NAT1 mRNA expression ( $P=0.0003$ and $P<0.0001$ respectively). (B) MCF-7 cells were transfected with either control miRNA ( $300 \mathrm{nmol} / \mathrm{l})$ or pre-miR-1290 precursor at 10-300 nmol/l and incubated for $36 \mathrm{~h}$. Expression levels of miR-1290 and mRNA levels of BCL2, FOXA1, MAPT, and NAT1 were measured by quantitative RT-PCR. Scatter plots show inverse correlation between miR-1290 expression and NAT1 mRNA expression

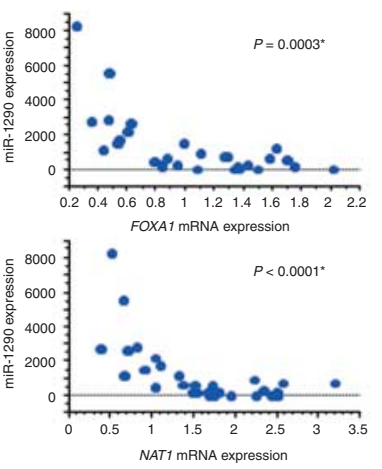

C T47D

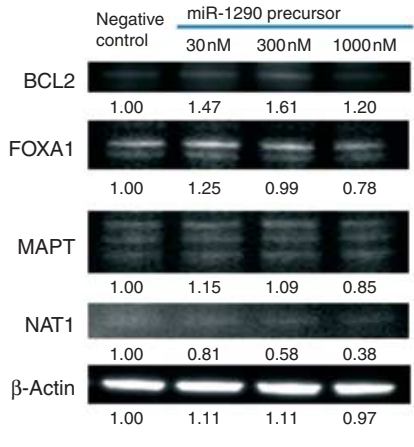

D $\quad$ MCF-7
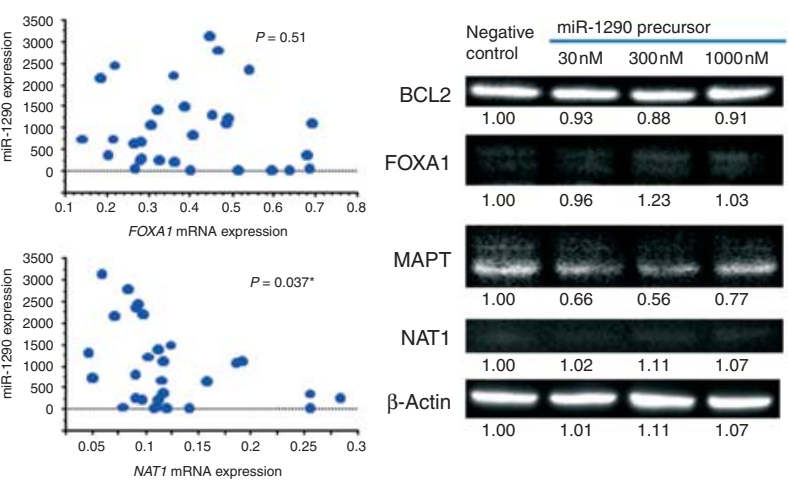

$(P=0.037)$. (C) T47D cells were transfected with either control miRNA (300 nmol/l) or pre-miR-1290 precursor at $30-1000 \mathrm{nmol} / \mathrm{l}$ and incubated for $48 \mathrm{~h}$. Protein expression of BCL2, FOXA1, MAPT, and NAT1 was assayed by western blot analysis. The number below the band represents the mean value from densitometry reading, relative to the negative control, which was set at 1.00. Representative results from one of the three experiments are shown. (D) MCF-7 cells were transfected with either control miRNA (300 nmol/l) or pre-miR-1290 precursor at 30-1000 nmol/l and incubated for $48 \mathrm{~h}$. Protein expression of BCL2, FOXA1, MAPT, and NAT1 was assayed by western blot analysis. The number below the band represents the mean value from densitometry reading, relative to the negative control, which was set at 1.00. Representative results from one of the three experiments are shown.
PgR and negatively associated with tumor grade in ER-positive breast cancer. Moreover, introduction of miR-1290 into estrogen-dependent breast cancer cells reduced FOXA1 expression. Because FOXA1 is a putative target of miR-1290 according to in silico analysis, we suggest that miR-1290 is a key factor for regulating FOXA1, which is associated with characteristics of ER-positive breast cancer.

Arylamine NATs, known as drug- and carcinogenmetabolizing enzymes, transfer an acetyl group from acetyl coenzyme A to arylamines (Sim et al. 2008). Several studies have shown higher mRNA and protein expression of NAT1 in ER-positive breast cancer compared with the expression in ER-negative disease (Perou et al. 2000, Adam et al. 2003, Tozlu et al. 2006, Wakefield et al. 2008). Moreover, it was reported that high expression of NAT1 was correlated with better outcome in ER-positive breast cancer (Bieche et al. 2004, Dolled-Filhart et al. 2006). Our results demonstrated that NAT1 mRNA expression was much higher in $\mathrm{ER}^{\text {high }} \mathrm{Ki} 67^{\text {low }}$ tumors than in $\mathrm{ER}^{\text {low }}$ Ki67 $7^{\text {high }}$ tumors by microarray analyses and that NAT1 protein expression by IHC showed positive correlation with expression levels of $\mathrm{ER}$ and $\mathrm{PgR}$ and negative correlation with expression levels of Ki67, tumor grade, and tumor size. In addition, introduction of miR-1290 into estrogen-dependent breast cancer cells strongly

Published by Bioscientifica Ltd. 


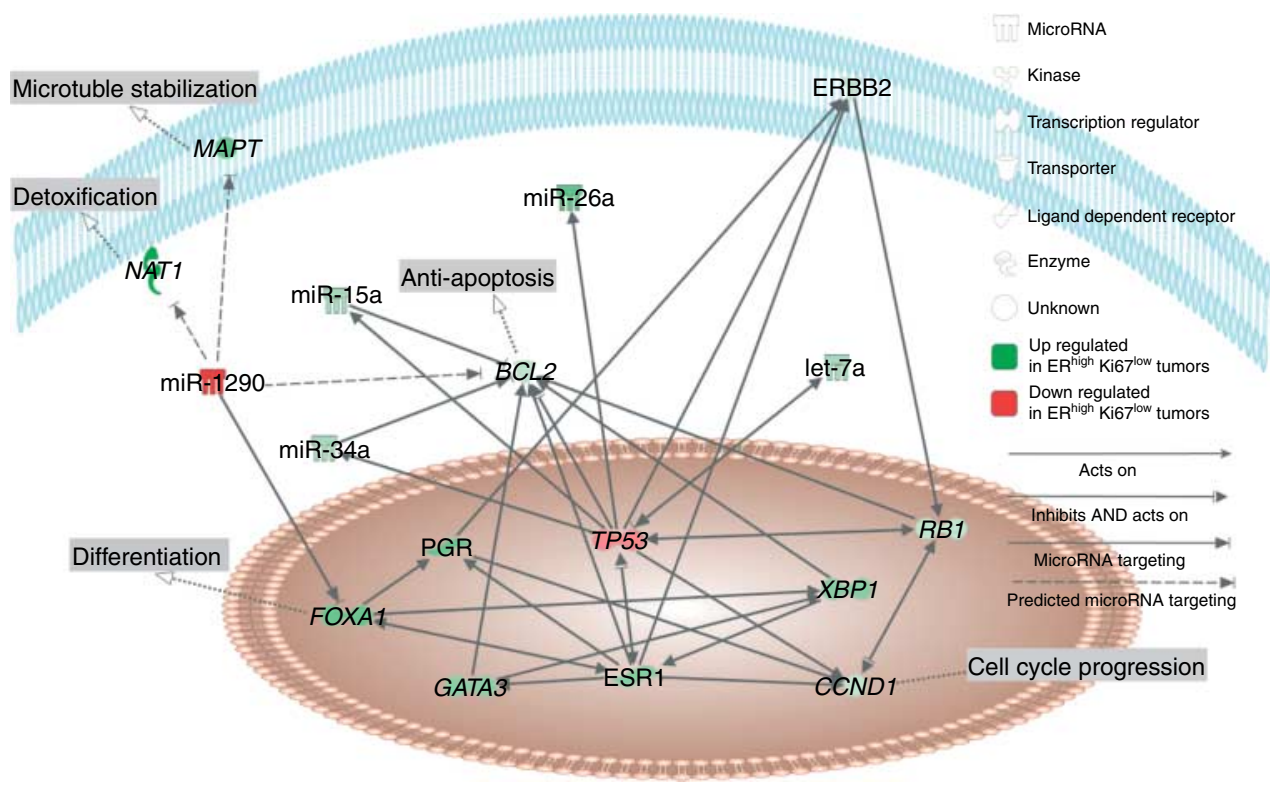

\section{Figure 3}

Interaction between miRNAs and putative target proteins that might be associated with characteristics of ER-positive breast cancer. Pathway analyses show five miRNAs (let-7a, miR-15a, miR-26a, miR-34a, and miR-1290) and nine target genes (BCL2, CCND1, FOXA1, GATA3, MAPT,

reduced NAT1 expression. Because NAT1, as well as FOXA1, is a putative target of miR-1290 according to in silico analysis, it is possible that miR-1290 also regulates NAT1, which will be associated with characteristics of ER-positive breast cancer.

BCL2 and MAPT are also potential targets of miR-1290 according to in silico analysis. BCL2 is an anti-apoptotic protein that has an anti-proliferative effect influencing cell cycle entry (Zinkel et al. 2006). BCL2 is an ER-induced gene, and its protein expression assessed by IHC has been shown to be a favorable prognostic marker in breast cancer (Callagy et al. 2006, Dawson et al. 2010). Our results also showed that expression levels of BCL2 were strongly and positively correlated with expression levels of ER and PgR in ER-positive breast cancer. It was recently reported that miR-195, miR-24-2, and miR-365-2 act as negative regulators of BCL2 through direct binding to their respective binding sites in the $3^{\prime}$-UTR of human BCL2 gene (Singh \& Saini 2012).

MAPT binds to both the outer and the inner surfaces of microtubules, leading to tubulin assembly and microtubule stabilization. As taxanes also bind to the inner surface of microtubules, MAPT might be considered to obstruct the function of these drugs. Most of the studies reported that MAPT expression has prognostic value,
$N A T 1, R B 1, T P 53$, and XBP1) that were picked up in our present analyses. These proteins and their pathways have diverse cellular functions, such as differentiation, detoxification, anti-apoptosis, cell cycle progression, and microtubule stabilization.

with high expression associated with favorable patient outcome. However, at the present time, there are few studies indicating that MAPT is a predictive marker for taxane-based chemotherapy (Baquero et al. 2011, Smoter et al. 2011). We demonstrated that expression levels of MAPT showed positive correlation with expression levels of ER and PgR and negative correlation with expression levels of Ki67, tumor grade, and tumor size in ER-positive breast cancer. Because miR-1290 did not decrease BCL2 or MAPT protein expression in ER-positive breast cancer cells in our analysis, BCL2 and MAPT might be regulated by other mechanisms.

Interaction between miRNAs and putative target proteins that might be associated with characteristics of ER-positive breast cancer is shown in Fig. 3, which was created by Ingenuity systems Pathway Analysis (http://www.ingenuity.com/index.html) and referring to previous reports (Gomez et al. 2007, Badve \& Nakshatri 2009, Clarke et al. 2009, O’Day \& Lal 2010).

Finally, our results indicated that let-7a was strongly upregulated in $\mathrm{ER}^{\text {high }} \mathrm{Ki} 67^{\text {low }}$ tumors and that expression levels of p53, one of the let-7a targets, was inversely correlated with let-7a expression in ER-positive breast cancer. The let-7 miRNA family is a group of tumor suppressing miRNAs that can inhibit both tumorigenesis 
and metastasis (Zhang et al. 2010). It was recently reported that let-7 family miRNAs, especially let-7a, let-7b, and let$7 \mathrm{i}$, were downregulated in breast cancer tissue compared with normal tissue and that let-7 miRNAs induced apoptosis in MCF-7 cells (Zhao et al. 2011). Thus, let-7 might have a role in ER-positive breast cancer.

In conclusion, this study indicates for the first time that miR-1290 and its potential targets, NAT1 and FOXA1, are strongly downregulated in $\mathrm{ER}^{\text {high }} \mathrm{Ki} 67^{\text {low }}$ tumors and are associated with characteristics of ER-positive breast cancer. miR-1290 could be a novel therapeutic target in ER-positive breast cancer.

\section{Supplementary data}

This is linked to the online version of the paper at http://dx.doi.org/10.1530/ ERC-12-0207.

\section{Declaration of interest}

The authors declare that there is no conflict of interest that could be perceived as prejudicing the impartiality of the research reported.

\section{Funding}

This work was supported in part by grant-in-aid for scientific research from Japan Society for the Promotion of Science.

\section{Author contribution statement}

$Y$ Endo designed the study, executed miRNA and mRNA expression profiling, target prediction and target validation, carried out immunostaining and western blotting, and drafted the manuscript. T Toyama, $\mathrm{N}$ Yoshimoto, M Iwasa, and T Asano provided tissue samples. S Takahashi assessed the immunostaining and western blotting. $Y$ Fujii participated in its design and coordination. $\mathrm{H}$ Yamashita conceived of the study and participated in its design, coordination, and manuscript writing. All authors read and approved the final manuscript.

\section{Acknowledgements}

The authors wish to thank Prof. Edith Sim and Dr Hilary Long (University of Oxford, UK) for kindly providing anti-NAT1 antibodies.

\section{References}

Adam PJ, Berry J, Loader JA, Tyson KL, Craggs G, Smith P, De Belin J, Steers G, Pezzella F, Sachsenmeir KF et al. 2003 Arylamine $N$-acetyltransferase- 1 is highly expressed in breast cancers and conveys enhanced growth and resistance to etoposide in vitro. Molecular Cancer Research 1 826-835.

Badve S \& Nakshatri H 2009 Oestrogen-receptor-positive breast cancer: towards bridging histopathological and molecular classifications. Journal of Clinical Pathology 62 6-12. (doi:10.1136/jcp.2008.059899)

Badve S, Turbin D, Thorat MA, Morimiya A, Nielsen TO, Perou CM, Dunn S, Huntsman DG \& Nakshatri H 2007 FOXA1 expression in breast cancer - correlation with luminal subtype A and survival. Clinical Cancer Research 13 4415-4421. (doi:10.1158/1078-0432.CCR07-0122)

Baquero MT, Lostritto K, Gustavson MD, Bassi KA, Appia F, Camp RL, Molinaro AM, Harris LN \& Rimm DL 2011 Evaluation of prognostic and predictive value of microtubule associated protein tau in two independent cohorts. Breast Cancer Research 13 R85. (doi:10.1186/ bcr2937)

Belian E, Kurucz R, Treue D \& Lage H 2010 Effect of YB-1 on the regulation of micro RNA expression in drug-sensitive and drug-resistant gastric carcinoma cells. Anticancer Research 30 629-633.

Bieche I, Girault I, Urbain E, Tozlu S \& Lidereau R 2004 Relationship between intratumoral expression of genes coding for xenobioticmetabolizing enzymes and benefit from adjuvant tamoxifen in estrogen receptor $\alpha$-positive postmenopausal breast carcinoma. Breast Cancer Research 6 R252-R263. (doi:10.1186/bcr784)

Blenkiron C, Goldstein LD, Thorne NP, Spiteri I, Chin SF, Dunning MJ, Barbosa-Morais NL, Teschendorff AE, Green AR, Ellis IO et al. 2007 MicroRNA expression profiling of human breast cancer identifies new markers of tumor subtype. Genome Biology 8 R214. (doi:10.1186/ gb-2007-8-10-r214)

Callagy GM, Pharoah PD, Pinder SE, Hsu FD, Nielsen TO, Ragaz J, Ellis IO, Huntsman D \& Caldas C $2006 \mathrm{Bcl}-2$ is a prognostic marker in breast cancer independently of the Nottingham Prognostic Index. Clinical Cancer Research 12 2468-2475. (doi:10.1158/1078-0432.CCR-05-2719)

Clarke R, Shajahan AN, Riggins RB, Cho Y, Crawford A, Xuan J, Wang Y, Zwart A, Nehra R \& Liu MC 2009 Gene network signaling in hormone responsiveness modifies apoptosis and autophagy in breast cancer cells. Journal of Steroid Biochemistry and Molecular Biology 114 8-20. (doi:10.1016/j.jsbmb.2008.12.023)

Dawson SJ, Makretsov N, Blows FM, Driver KE, Provenzano E, Le Quesne J, Baglietto L, Severi G, Giles GG, McLean CA et al. 2010 BCL2 in breast cancer: a favourable prognostic marker across molecular subtypes and independent of adjuvant therapy received. British Journal of Cancer 103 668-675. (doi:10.1038/sj.bjc.6605736)

Dolled-Filhart M, Ryden L, Cregger M, Jirstrom K, Harigopal M, Camp RL \& Rimm DL 2006 Classification of breast cancer using genetic algorithms and tissue microarrays. Clinical Cancer Research 12 6459-6468. (doi:10.1158/1078-0432.CCR-06-1383)

Dowsett M, Allred C, Knox J, Quinn E, Salter J, Wale C, Cuzick J, Houghton J, Williams N, Mallon E et al. 2008 Relationship between quantitative estrogen and progesterone receptor expression and human epidermal growth factor receptor 2 (HER-2) status with recurrence in the arimidex, tamoxifen, alone or in combination trial. Journal of Clinical Oncology 26 1059-1065. (doi:10.1200/JCO.2007.12.9437)

Esquela-Kerscher A \& Slack FJ 2006 Oncomirs - microRNAs with a role in cancer. Nature Reviews. Cancer 6 259-269. (doi:10.1038/nrc1840)

Goldhirsch A, Wood WC, Coates AS, Gelber RD, Thurlimann B \& Senn HJ 2011 Strategies for subtypes - dealing with the diversity of breast cancer: highlights of the St. Gallen International Expert Consensus on the Primary Therapy of Early Breast Cancer 2011. Annals of Oncology 22 1736-1747. (doi:10.1093/annonc/mdr304)

Gomez BP, Riggins RB, Shajahan AN, Klimach U, Wang A, Crawford AC, Zhu Y, Zwart A, Wang M \& Clarke R 2007 Human X-box binding protein-1 confers both estrogen independence and antiestrogen resistance in breast cancer cell lines. FASEB Journal 21 4013-4027. (doi:10.1096/fj.06-7990com)

Harvey JM, Clark GM, Osborne CK \& Allred DC 1999 Estrogen receptor status by immunohistochemistry is superior to the ligand-binding assay for predicting response to adjuvant endocrine therapy in breast cancer. Journal of Clinical Oncology 17 1474-1481.

Hurtado A, Holmes KA, Ross-Innes CS, Schmidt D \& Carroll JS 2011 FOXA1 is a key determinant of estrogen receptor function and endocrine response. Nature Genetics 43 27-33. (doi:10.1038/ng.730)

Iorio MV, Ferracin M, Liu CG, Veronese A, Spizzo R, Sabbioni S, Magri E, Pedriali M, Fabbri M, Campiglio M et al. 2005 MicroRNA gene 
expression deregulation in human breast cancer. Cancer Research 65 7065-7070. (doi:10.1158/0008-5472.CAN-05-1783)

Kondo N, Toyama T, Sugiura H, Fujii Y \& Yamashita H 2008 miR-206 expression is down-regulated in estrogen receptor $\alpha$-positive human breast cancer. Cancer Research 68 5004-5008. (doi:10.1158/0008-5472. CAN-08-0180)

Krol J, Loedige I \& Filipowicz W 2010 The widespread regulation of microRNA biogenesis, function and decay. Nature Reviews. Genetics 11 597-610. (doi:10.1038/nrg2843)

Mattie MD, Benz CC, Bowers J, Sensinger K, Wong L, Scott GK, Fedele V, Ginzinger D, Getts R \& Haqq C 2006 Optimized high-throughput microRNA expression profiling provides novel biomarker assessment of clinical prostate and breast cancer biopsies. Molecular Cancer 524. (doi:10.1186/1476-4598-5-24)

Mehta RJ, Jain RK, Leung S, Choo J, Nielsen T, Huntsman D, Nakshatri H \& Badve S 2012 FOXA1 is an independent prognostic marker for ER-positive breast cancer. Breast Cancer Research and Treatment 131 881-890. (doi:10.1007/s10549-011-1482-6)

O'Day E \& Lal A 2010 MicroRNAs and their target gene networks in breast cancer. Breast Cancer Research 12 201. (doi:10.1186/bcr2484)

Parker JS, Mullins M, Cheang MC, Leung S, Voduc D, Vickery T, Davies S, Fauron C, He X, Hu Z et al. 2009 Supervised risk predictor of breast cancer based on intrinsic subtypes. Journal of Clinical Oncology 27 1160-1167. (doi:10.1200/JCO.2008.18.1370)

Perou CM, Sorlie T, Eisen MB, van de Rijn M, Jeffrey SS, Rees CA, Pollack JR, Ross DT, Johnsen H, Akslen LA et al. 2000 Molecular portraits of human breast tumours. Nature 406 747-752. (doi:10.1038/35021093)

Ross-Innes CS, Stark R, Teschendorff AE, Holmes KA, Ali HR, Dunning MJ, Brown GD, Gojis O, Ellis IO, Green AR et al. 2012 Differential oestrogen receptor binding is associated with clinical outcome in breast cancer. Nature 481 389-393. (doi:10.1038/nature10730)

Sim E, Walters K \& Boukouvala S 2008 Arylamine $N$-acetyltransferases: from structure to function. Drug Metabolism Reviews 40 479-510. (doi:10.1080/03602530802186603)

Singh R \& Saini N 2012 Downregulation of BCL2 by miRNAs augments drug induced apoptosis: combined computational and experimental approach. Journal of Cell Science 125 1568-1578. (doi:10.1242/jcs. 095976)

Smoter M, Bodnar L, Duchnowska R, Stec R, Grala B \& Szczylik C 2011 The role of tau protein in resistance to paclitaxel. Cancer Chemotherapy and Pharmacology 68 553-557. (doi:10.1007/s00280-011-1696-7)

Sorlie T, Tibshirani R, Parker J, Hastie T, Marron JS, Nobel A, Deng S, Johnsen H, Pesich R, Geisler S et al. 2003 Repeated observation of breast tumor subtypes in independent gene expression data sets. PNAS $\mathbf{1 0 0}$ 8418-8423. (doi:10.1073/pnas.0932692100)

Tozlu S, Girault I, Vacher S, Vendrell J, Andrieu C, Spyratos F, Cohen P, Lidereau R \& Bieche I 2006 Identification of novel genes that co-cluster with estrogen receptor $\alpha$ in breast tumor biopsy specimens, using a large-scale real-time reverse transcription-PCR approach. Endocrine-Related Cancer 13 1109-1120. (doi:10.1677/ erc.1.01120)

Wakefield L, Robinson J, Long H, Ibbitt JC, Cooke S, Hurst HC \& Sim E 2008 Arylamine $\mathrm{N}$-acetyltransferase 1 expression in breast cancer cell lines: a potential marker in estrogen receptor-positive tumors. Genes, Chromosomes \& Cancer 47 118-126. (doi:10.1002/gcc.20512)

Wulfken LM, Moritz R, Ohlmann C, Holdenrieder S, Jung V, Becker F, Herrmann E, Walgenbach-Brunagel G, von Ruecker A, Muller SC et al. 2011 MicroRNAs in renal cell carcinoma: diagnostic implications of serum miR-1233 levels. PLoS ONE 6 e25787. (doi:10.1371/journal.pone. 0025787)

Yamashita H, Iwase H, Toyama T \& Fujii Y 2003 Naturally occurring dominant-negative Stat5 suppresses transcriptional activity of estrogen receptors and induces apoptosis in T47D breast cancer cells. Oncogene 22 1638-1652. (doi:10.1038/sj.onc.1206277)

Yamashita H, Ando Y, Nishio M, Zhang Z, Hamaguchi M, Mita K, Kobayashi S, Fujii Y \& Iwase H 2006 Immunohistochemical evaluation of hormone receptor status for predicting response to endocrine therapy in metastatic breast cancer. Breast Cancer 13 74-83. (doi:10.2325/jbcs.13.74)

Yoshimoto N, Toyama T, Takahashi S, Sugiura H, Endo Y, Iwasa M, Fujii Y \& Yamashita H 2011 Distinct expressions of microRNAs that directly target estrogen receptor $\alpha$ in human breast cancer. Breast Cancer Research and Treatment 130 331-339. (doi:10.1007/s10549011-1672-2)

Zhang J \& Ma L 2012 MicroRNA control of epithelial-mesenchymal transition and metastasis. Cancer Metastasis Reviews 31 653-662. (doi:10.1007/s10555-012-9368-6)

Zhang H, Li Y \& Lai M 2010 The microRNA network and tumor metastasis. Oncogene 29 937-948. (doi:10.1038/onc.2009.406)

Zhao Y, Deng C, Wang J, Xiao J, Gatalica Z, Recker RR \& Xiao GG 2011 Let-7 family miRNAs regulate estrogen receptor $\alpha$ signaling in estrogen receptor positive breast cancer. Breast Cancer Research and Treatment 127 69-80. (doi:10.1007/s10549-010-0972-2)

Zinkel S, Gross A \& Yang E 2006 BCL2 family in DNA damage and cell cycle control. Cell Death and Differentiation 13 1351-1359. (doi:10.1038/sj. cdd.4401987)

Received in final form 29 October 2012

Accepted 23 November 2012

Made available online as an Accepted Preprint

26 November 2012 http://erc.endocrinology-journals.org DOI: $10.1530 /$ ERC-12-0207
(C) 2013 Society for Endocrinology Printed in Great Britain
Published by Bioscientifica Ltd. 